part of our society than in the way they accept its implicit assumptions. Of these assumptions, none is more pervasive than the idea that victory is the final test. In American life, there are "winners" and there are "losers,". and that exhausts the categories. An idea "works" or "doesn't work." The ultimate sin in our society is to lose.

Therein lies the truth of Mr. Rap Brown's celebrated remark about cherry pie. Americaijs are rot by nature any more violence-prone than, say; the Swiss, but their cultural imperatives reward violence a great deal better. This is the lesson of the ghetto riots; it is the lesson of the "love children": turned into workers in bomb factories; it is, abore all, the lesson of Vietnam.

What then? Is violence simply the way of the world? The passage in Matthew (11;12) alluded to in the title of this editorial (and famitiar to readers of the late Flannery O'Connor) says, "From the days of fohn the Baptist until now the Kingdom of Heaven has suffered violence, and men of violence take it by force." The statement occurs in the context of a waming of Divine judgment on those who refuse to accept prophets when they appear.

How to distingrish the true prophet from the false one is one of the most vexing problems of history, no less so in a society which specializes in marketing prophets much as any other commodity. One might very well argne that the problen is even more difficult in a media society. It is reassuring to argue that revilision against the war in Vietnam is due largely to seeing the normal violence of war on television in our living rooms. But one wonders if the sequence in Follini's Satyricon, where a man's arm is actually chopped off as part of a theatrical performance, is not simply a reminder of ancient cruelty but also a piediction of things to enme.

Non-violence has always received sentimental lip service in this world, but little else. Gandhi and Martin Luther King, Jr. were not even allowed to die non-violently, solet us not be too glib about forswearing violence. Perhaps the time is coming when the sheer violence of our society will bring forth, in desperation, a new crop of advocates of non-violence as the atomic bomb produced a new hreed in the nuclear picifists.

Let us hope so. In the meantime, we nust struggle with the problems of how to produce a society based as littlc as possible on coercion; a socicty that truly does value multiplicity rather than conformity but yet does not disintegrate. Those problems arc complex and difficult, but there is one thing that is necessary before attempt ing any solution. We must stop lying to one another and, more important, to ourselves. There is no benign violence. The Chicago Police and the Weathermen, the F.B.I and the Black Panthers are morally in the same boat. We may judge one necessary and the other not, but that is a prudential judgment only. For violence is a psychotic whore; she will sleep with any of us in turn or all together, but in the end she will turn and kill us all.

Arthur J. Moore

\section{DECEPTION AND POLICY}

On the human affectivity scale, the love of truth holds no primacy. There are a lot of things we like more. Ease and clarity are examples. And when deceits promote ease and clarity, we fall in love with deception and resist the truth as we would a rival. None of us are all that alien to Elwood P. Dowd, the visible hero of II arivet who, when urged to le realistic, professed that he had tried reality and found it wanting.

Now let it be said that ease and clarity are no mean values. And yet, securing them in a world of mounting ambiguity and complexity often requires considerable sacrifice at the level of truth. A truly oljective view of today's social realities brings $i s$ into agonizing confrontation with $a b$ surdities, threats, and contradictions. The effort for oljectivity yields no ease and little clarity. The guest for truth is a rough and abrasive pilgrimage. Deception, imposed or self-administered, is the casy and obrious solution. Small wonder, then, that deception is in such strong dentand and copions stupply on our current national scene.

No vialyle government, of course, has'ever been :naware of the possibilities of deception. Deception, conccived outside of comtext, is a morally nentrat notion. In certain contests, it can be good. There ate tender deceptions that preserve relitionships from inevitable weakness and there are strategic deceptions that make diplomacy and politics feasible arts. Deception can serve and be good. It carr also dominate and he bad.

The Nixon Administration did not initiate po litical deception any more than Johnson invented incredibility: This Administration has, however, been emitting some distinctive and high-profile deceptions to an avidly receptive nation. But now some of the tangled wehs that have heen woven 
are showing tattered corners and are in danger of being swiftly unraveled.

Retreat with victory (something of a first in the history of strategy) was called for in Indo-China. It sounded good, and two-thirds of the nation bleated approval according to an early Gallop poll. But now the effects of sich a power shift are becoming apparent. Concrete developments are shaking the abstract deceits housed in the term "Vietnamization." Perhaps even our morbid devotion to the Thieu dictitorship is becoming ready for popular review.

Retreat with victory is being sounded on a more muted trumpet in the area of American racism. The President's recent statement on school desegregation said that "under appropriate conditions, racial integration in the classroom can be a significant factor in improving the quality of education for the disadvantaged." Given the Administration's wan approach to civil rights, this hedged statement represents a retreat toward the lowlands of "separate but equal." Read against the background music of the Gridiron Club piano duet, the statement is an ineffective deception. American blacks are among those least deceived. According to a Harris poll, only three per cent look to this Administration for leadership in racia] affairs, whereas sixty-three per cent anticipated such leadership from the Administrations of Kennedy and Johnson. Thin deceptions are the most dangerous.

The areat of neclear arms control would scem most in need of a chaste objectivity. Yet patterns of deception are notithly present here and help account for the reasonless, spiraling overkill potential. One example, inherited and refitted by the present Administration, affects the distinction between offensive and defensive nuclear weapons. Development of the A.B.M. is justified because the A.B.M. is a defensive weapon. This seems reasonable since it is directed to incoming missiles and not to foreign sites. Fudged in this discussion, however, is the fact that so-called offensive missiles are also defensive. In fact, if one puts any stock in the traditional principle that war must do more good than harm to be justified, then the only rational and moral use of "offensive" nuclears is their defensive deterrence by way of a balance of terror during the search for disarmanent.

Additional weapons of any sort are not defensive but provocative. Given our present overkill capacity, our true posture now is one of overdefense. What is needed is less defense-by a scaling down of excessive deterrence systems.
Bold initiative in negotiations is the prime defensive need today. But the deceptions here are as powerful as they are expensive.

"Strict constnuction" is a delicionsly vague and therefore attractive rubric of deception. This versatile term has been used by the Administration to portray an edifying bard-core love for the Constitution. But again, the indices of deception are numerous. It is not at all a hard-core constitutionality that chatacterizes the Administration's reaction to the Supreme Conrt's pressing on the desegregation timetable, or to the events in Lamar or in Manitec County. The letter to Senator Saxbe on presidential rights was also a little less than a paragon of constitutional expertise.

Foreign policy wonld seem to demand a degree of deception since unmitigated candor between nations is neither expected nor desired. But what about a presidential report on foreign policy to the Congress? ITans Morgenthat cam conclude an analysis of that 40,000 -word document noting that "whatever the merits and defects of this document are, they can only have a tenuous relation to the foreign policy ictually pursued by the Nixon Administration" (Now Republic, March 21).

Enough is being said these days on the subrhetoric realities that are involved in balancing the Supreme Court, bringing us together, and the evil freedom of the liberal press. Indeed, the public's thirst for easy deceptions is showing signs of leing slaked. Hopefully this new mood will not upset the delicute seduction the president has been achieving in making his liberal program for welfare reform seem like an assault on indolence. Matybe too, the President will be able to mateh the deceptiveness of de Cantle's Algerian exodus by convineing his loyalty miajority that withdrawal from Indo-China is really not in defeat. If welfare reform and the end of the Vietnamese Crusade can only be ended by deceptions on the grand Nixonian scale, so be it! Daniel C. Maguire

Arthur l. Moore, the first of this month's guest editorial writers, has had a long aissociation with CRIA dating from his participation in the first seminar on Ethics and Foreign Policy conducted by the organization. He is editor of World Outlook.

Daniel C. Mayuirr, ilssociate professor of Christian Ethies at The Catholic University of America, is a memler of the CRIA Study Group. 